$J J M L L$

\title{
The Extent of Using Modern Assessment Strategies and Tools by Teachers of English Language in an EFL Context
}

\author{
Amal AlNatour, Dima Hijazi \\ Language Center, Yarmouk University, Jordan \\ Heba AlZuraiqih \\ Al Qalqashandi for Writing and Research, Jordan
}

Received on: 6-8-2019

Accepted on: 16-12-2019

\begin{abstract}
The study aims at investigating the extent of using modern assessment strategies and tools by Jordanian Teachers of English Language in an EFL context, for it is an integral component of the teaching and learning process. Gender, experience and qualifications were taken into account as variables of the study, which was limited to teachers of English in an EFL context for the academic year 2018/2019.A random sample of 43 teachers from Irbid first governorate in Jordan was selected. A descriptive analytical method using a five-likert scale as an instrument was adapted to achieve the goals of the study. The results show that the level of using modern assessment strategies and tools by English teachers to assess students' understanding and enhance their learning ranges between medium and low but is mostly low. It is noted that the implementation of some items that represent traditional assessment are higher than the other items. The final results indicate that teachers tend to use traditional assessment strategies for different reasons presented in the discussion. Moreover, the results show that there are no statistically significant differences $(\alpha=0.05)$ due to gender, experience, or qualifications.
\end{abstract}

Keywords: Assessment strategies, EFL context, traditional assessment strategies, modern assessment strategies.

\section{Introduction}

English is the language of globalization, and its learning has become of primordial importance for most people around the world nowadays. As a result, students need to master this international channel of communication to be able to cope with the new changes in the world. English is taught as a foreign or second language in varied contexts all around the world. In fact, policy makers at educational institutions have recognized the importance of English and made a lot of efforts to improve students' English language competencies through developing teachers' knowledge in three core domains: planning, methods of teaching and assessment (National Research Council 2000).

Assessment is a pivotal component of the teaching -learning process (Goodrum et al. 2001) because of its critical importance for both teachers and students. It is one of the most important tools of education. It is the bridge that links teaching and learning together since it allows teachers to know if their teaching practices lead to the desired learning (Wiliam 2013). Dunn et al. (2003, 3) stated that "researchers have placed student assessment at the peak of the pyramid as regards its importance in determining student approaches to learning".

@2020 JJMLL Publishers/Yarmouk University. All Rights Reserved 


\section{AlNatour, Hijazi and AlZuraiqih}

The term assessment has various definitions according to the role it plays in teaching and learning. As defined in the Glossary of Education Reform (2014), assessment refers to "the wide variety of methods or tools that educators use to evaluate, measure, and document the academic readiness, learning progress, skill acquisition, or educational needs of students". Meanwhile, it is defined by Allen $(2004,4)$ as "a framework for focusing attention on student learning and for provoking meaningful discussions of program objectives, curricular organization, pedagogy, and student development". Angelo (1995, 7) stated that assessment is "an ongoing process aimed at understanding and improving student learning. It involves making expectations explicit and public; setting appropriate criteria and high standards for learning quality; systematically gathering, analyzing, and interpreting evidence to determine how well performance matches those expectations and standards; and using the resulting information to document, explain, and improve performance". For their part, Huba and Freed $(2000,8)$ defined assessment as "the process of gathering and discussing information from multiple and diverse sources in order to develop a deep understanding of what students know, understand, and can do with their knowledge as a result of their educational experiences; the process culminates when assessment results are used to improve subsequent learning".

Assessment, as an indispensable process, entails benefits related to students, teachers, and educational programs as well. For students, assessment enables them to learn and to track their progress towards achieving the goals of the course (Gardiner 1994). It also helps them to determine their points of strengths or weaknesses in order to work harder, to modify and develop their learning if their performance in the classroom is poor, and to become more responsible and motivated towards their learning. Likewise, it provides teachers with clear insights into the genuine level of their students, their problems and difficulties, to enable them to reevaluate their ways of teaching, to develop their teaching competences, to eliminate and process students' problems and to provide them with better and more helpful feedback.

There are three major types of assessment: diagnostic, formative, and summative assessment. Diagnostic assessment enables teachers to find out prior knowledge about each individual student before explaining any topic, and this helps them to plan appropriate and meaningful instruction (Dumit 2012).Formative assessment (assessment for learning) enables teachers to collect information about students' learning needs during the learning process and before the summative assessment to modify their teaching practices according to these needs and to provide students with ongoing feedback to enhance their achievement (Looney 2011). Heritage $(2008,2)$ indicated that the purpose of formative assessment is to provide feedback to teachers and students during the course of learning about the gap between students.

For its part, summative assessment enables teachers to make final judgments about the learning that has been completed, the performance of their students and the appropriateness of their teaching practices after a certain period of instruction (Chappuis and Chappuis 2007). Shepherd and Godwin (2004, 4) pointed out that summative assessment is usually quantitative.

In assessing learning outcomes, the traditional ways of assessment such as tests or papers are not always the case; there are other types of assessment including "focus groups, interviews, electronic 
The Extent of Using Modern Assessment Strategies and Tools by Teachers of English Language in an EFL Context

portfolios, and surveys" (Gahagan et al. 2010, 6). These types can sometimes identify some strength or weak points regarding the learning process that traditional methods can vaguely measure. Pellegrino, Chudowsky, and Glaser (2001) stated that although there are many tools used for assessment, the important question to raise is about the most effective kind of assessment to implement.

Since measuring students' performance and understanding is the aim of assessment, teachers use a variety of assessment methods, strategies and tools underlying different names, whether traditional or authentic/alternative. The majority of teachers depend on the traditional tools and strategies: multiplechoice tests, true/false tests, short answers, and essays (Simonson et al. 2000).

On the other hand, the authentic or alternative tools and strategies of assessment depend on the engagement of students in the learning process by performing tasks themselves. This tool, with the aid of certain directions given by teachers, is able to demonstrate students' aptitude. Alternative assessment puts the theories taught by teachers into practice. Janisch, Liu, and Akrofi $(2007,221)$ defined the content alternative assessment tools to include considering learners as constructors of knowledge; finding authentic materials and activities; employing dynamic, ongoing evaluation tools; and empowering students.

By asking teachers what modern assessment strategies they most likely use, several strategies are stated including: open-ended and brainstorming questions that lead students to respond with long answers in a written or spoken form. Peer instruction is also a strategy teachers rely on in the process of assessing students' understanding. In certain cases, take-home exams are used to measure student's level of grasping, and consequently, expressing their understanding of particular concepts teachers address. By the end of the term, teachers form groups of students to tackle an issue students know about to present projects that involve all language skills: writing, listening, reading and or speaking as well as comprehension using various forms of questions.

\section{Problem of the study}

The nature of assessment used by Teachers of English Language is of great importance because it is an integral component of the teaching and learning process. Many researchers in the field such as (Yamtim and Wongwanich 2014, Kanjee and Mthembu 2015) asserted that teachers' assessment literacy is low and a large number of them face difficulties in assessing their students appropriately. This study is the first to address such a problem in Jordan. Teachers need to vary their methods and strategies of assessment because using the same methods of assessment may negatively affect students day after day. Using varied ways of assessment can help teachers to assess students' different learning approaches taking into consideration their needs and their points of weaknesses and strengths.

\section{Purpose and Questions of the Study}

The purpose of this study is to investigate the level of using modern assessment strategies and tools by Jordanian teachers of English in an EFL context in Irbid first governorate, in light of gender, experience and qualifications, and their appropriateness in achieving the teaching/learning goals set. 
AlNatour, Hijazi and AlZuraiqih

In this study, the researchers attempt to answer the following questions:

1- What is the most common method of assessment used: traditional or modern assessment methods?

2-Are there any statistically significant differences at $(\alpha=0.05)$ in the assessment strategies and tools used by Teachers of English Language due to gender, experience and qualification variables?

\section{Significance of the study}

The importance of this study stems from the fact that only a few studies have been conducted in EFL contexts, according to the researchers' knowledge, to investigate the level of using modern assessment strategies and tools by Teachers of English Language in Jordan. The results of this study may provide additional insights into English teachers' assessment strategies in a context in which English is taught as a foreign language. Moreover, this study may be used as a reference for other scholars to conduct further research in other educational contexts. The study may reveal one of the reasons behind students' weakness in English since the lack of using effective assessment methods may negatively affect the educational process. Lastly, the current results may encourage policy makers to conduct efficient training programs to develop teachers' assessment literacy concerning the new methods of assessment and determine how to apply them appropriately to assess students and enhance their learning capacities to be in line with current changes, so that they are not left behind as the world moves on.

\section{Operational Definitions of Terms (based on the current study)}

-Assessment strategies: a variety of traditional or alternative strategies used by teachers of English to enhance their students' learning.

-EFL Context: a context in which English is taught as a foreign language.

-Modern assessment strategies: They are the systematic modern procedures of engaging learners to perform real-life tasks on the basis of the items they are informed to measure their knowledge and skills, not their abilities to memorize or recall, in order to improve their process of learning.

- Traditional assessment: It is the systematic standard testing methods with short or limited answers teachers use to measure students' ability to memorize and encourages rote-learning.

-Jordanian EFL teachers: Male and female teachers of English Language from Jordan, limited to Irbid first governorate, who teach English to Jordanian students whose first language is not English.

\section{Limitations of the Study}

The generalization of the results of this study is limited to teachers of English in Irbid first governorate (as an example of a foreign context), for the academic year 2018/2019 in Irbid, Jordan. It is also limited to the instrument of the study which is a five - likert scale and to three variables which are gender, experience and qualification. 
The Extent of Using Modern Assessment Strategies and Tools by Teachers of English Language in an EFL Context

\section{Literature Review}

Many studies in the related literature discuss the meaning of both traditional and alternative ways of assessment and compare between them mentioning their advantages and disadvantages. However, very few studies have investigated the practical use of modern ways of assessment by teachers in the classroom nowadays especially that we live in a continuously changing world that focuses on the innovative approaches of learning.

Investigating assessment perceptions and practices in the advanced foreign language classroom is a report introduced by Shohamy et al. (2008). The report is a survey -based study designed to investigate Advanced Language Proficiency (ALP) and consists of what is said to be known as two major components: "'the what' (e.g., how the language is perceived and conceptualized) and the 'how', (e.g., the very methods used to assess this knowledge)" (p. 4). For advanced language proficiency (ALP), teachers play a significant role in the process of class assessment. However, teachers' perception, which includes many factors such as proficiency and level of education, must be taken into account. After analysis, teachers agree that all advanced learners should be able to engage in a conversation about everyday life, read a newspaper, and construct narratives about current events. (p.13) In ALP, teachers opt for functionality over accuracy as part of communicative competence. Though the report states that certain students of certain backgrounds, such as Arabic, have more difficulty achieving ALP than others, yet it is still possible to accomplish. "...even though the learner of Arabic cannot perform in the same way as the learner of Spanish, this does not disqualify the former from having achieved ALP" (p. 16). Teachers stress out certain ALP "procedures such as portfolios, performance tasks, essays, and rubrics and that assessment is always an on-going process with a formative dimension." (p. 25) Nevertheless, teachers continue to use traditional methods of assessment even when they use advanced innovative methods in teaching. The most common assessment was traditional tests and quizzes format. The current study shares the aim with this report, namely, study the assessment tools Jordanian teachers use in class. It also supports the idea of the factors used to assist teachers' perception that affects ALP learning through the questionnaire conducted.

Mussawy (2009) conducted a work to serve two purposes: to investigate class assessment of preservice teachers' perceptions, and to examine faculty members' perceptions as a secondary aim. In addition, the study is a contribution to class assessment methods and how they can enhance students' learning process. It differentiates between two types of assessment used: "formative" and "summative". Teachers are nowadays shifting to the new methods, i.e. the ones that depend on evaluating students' engagement in activities during class. It also distinguishes between measuring achievement using traditional testing and a paradigm that offers "higher-order knowledge and skills" (p. 8). The type of assessment students need is the one that enhances performance and provides future aid; students' engagement in the assessment process is crucial, as many have suggested (Dochy and McDowell, 1997; Nitko 1989; Black and Wiliam 1998; Birenbaum and Dochy 1996; Wiliam and Thompson, 2008). (pp. 15-6) 
AlNatour, Hijazi and AlZuraiqih

The researcher also exposes here a number of assessment types that should be used in schools with their definitions, characteristics and positive and negative aspects as investigated by various scholars. Among these are Portfolios, Self/ Peer assessment, Performance-Based/ Interview-Based/ Play-Based Assessment, and Questioning.

Rahman, Bahu and Ashrafuzzaman (2011) explored the nature of English language classroom assessment and feedback practiced within Junior Secondary schools of Bangladesh. A qualitative approach was used to collect data by using classroom observation checklists, English teachers' and head teachers' interview schedules and Focus Group Discussions (FGDs) with students. Thematic analysis was conducted to pull out the findings of the study which showed that teachers assessed the students' learning through questioning and the questions were closed-ended by nature. Most of the students liked written assessments. In the classroom, teachers provided only verbal feedback to the students and in the observation it was found that teachers gave feedback on few occasions. Teachers recommended that listening and speaking test items should be included within the national assessment system.

Forutan (2014) evaluated the performance of EFL learners on writing methodology in the traditional and alternative assessments strategies. The sample of the study includes male and female university students in an advanced writing course. A knowledge-telling model shows that advanced writers focus more on editing and using internal material in creating the content, unlike beginners who tend to make less revising of the written material. The study was conducted in two stages. Firstly, a traditional writing task was given the participants, who were included in the study sample, by proposing guided questions to obtain brainstormed answers; then, a video and reading passage, related to the subject provided, were given to them. Finally, the researchers have noticed that most studies concentrate on using alternative assessment strategies and how they contribute to students' level of education. These studies even sometimes prefer assessing functionality over accuracy and discussing what should be used as an alternative way of teaching methodology and consequently assessment strategies. However, most of them do no focus on the "level" of using these strategies and whether or not teachers prefer using traditional ways of assessment over alternative strategies.

Alternative assessment is used as a means for educational reform due to the increasing awareness of the influence of testing on curriculum and instruction. Currently, traditional assessment, namely testing, is challenged by alternative assessment approaches. Quansah (2018) compared traditional assessment procedures (e.g., multiple choice and essay) with performance and portfolio assessments with the view of unearthing which assessment procedure should be adopted in this current generation.

Quansah concluded that it is important for teachers to utilize the form of assessment procedure (whether traditional or alternative) which will help in achieving their learning objectives in a feasible manner. 
The Extent of Using Modern Assessment Strategies and Tools by Teachers of English Language in an EFL Context

\section{Method and Procedure}

This part of the study presents the methodology that the researchers followed in this study. It includes the population, the sample, the instrument along with its validity and reliability, the dependent and independent variables and the procedures of the study.

\section{Design of the Study}

A descriptive analytical method was used in this study. This method studies a certain issue or phenomenon in order to collect information that answers the questions of the study.

\section{The population and sample of the study}

The population of this study was 639 which was composed of all male and female English language teachers in Irbid first governorate in Jordan for the academic year 2018/2019. A random sample of 45 teachers was selected. After the questionnaire was distributed, two questionnaires were excluded since the answers were not clear enough. As a result, the total number of the sample became 43. Table (1) shows the distribution of the study sample.

Table 1: Frequencies and Percentages of the Sample according to Study Variables

\begin{tabular}{lccc}
\hline Variables & Categories & Number & Percentage \\
\hline Gender & Male & 28 & $65 \%$ \\
& Female & 15 & $35 \%$ \\
\hline Experience & 5 years or less & 15 & $35 \%$ \\
& 6-10 years & 17 & $40 \%$ \\
& 10 years or more & 11 & $25 \%$ \\
\hline Qualifications & BA & 20 & $47 \%$ \\
& Higher Diploma & 15 & $35 \%$ \\
& M.A. & 8 & $18 \%$ \\
\hline & Total & 43 & $100 \%$ \\
\hline
\end{tabular}

\section{Instrument of the Study}

To identify the assessment strategies used by Teachers of English Language to enhance students' learning, a questionnaire was constructed to collect data according to the following procedures:

First: Reviewing the related literature on the subject of the strategies used for students' assessment.

Second: Analyzing the content of the educational bulletins on the assessment strategies issued by the Jordanian Ministry of Education, and then restructuring a number of items. The questionnaire prepared in its initial form consisted of (25) items, in which the items were constructed to be measurable and observable in order to have a precise idea of the types of assessment strategies used by English teachers. 


\section{Content validity of the attitudinal questionnaire}

In order to verify the validity of the questionnaire, the researchers relied on itsapparent validity. It was presented to a group of five Jury who were experts in the field. They were asked to express their opinions about the formulation of the items and their linguistic integrity. The formulation of some items was modified in terms of construction and thereby achieved the apparent validity of the instrument. The arbitrators proposed that items (24 and 25) should be deleted. They also suggested that item (19) should be divided into two separate items instead of one to make the final version of the questionnaire consist of 24 items. (Please, refer to the original questionnaire in Appendix A)

\section{Construct Validity of the questionnaire}

In order to construct the validity of the questionnaire, the researchers chose a pilot group of $16 \mathrm{EFL}$ teachers from outside the participants of the study. The correlation coefficient of the items with the whole questionnaire was calculated (Appendix B). It is shown that the values of the correlation coefficient of the items with the whole questionnaire ranged from (0.64-0.92) and that reflects a good construct validity of the questionnaire.

\section{Reliability of the study instrument}

To ensure the reliability of the study instrument, it was verified by applying and re-applying it (testretest strategy) two weeks later to 16 English teachers not included in the original study sample. Pearson correlation coefficient between the estimates was then measured at both times and it was (0.87). Cronbach's coefficient alpha was used to calculate the internal consistency coefficient of the items included in the questionnaire and it was (0.89). These values are considered appropriate for the purpose of this study.

\section{Data Analysis}

After the questionnaires were collected from the study sample, the answer scale for the questionnaires was translated from a verbal to a quantitative scale by giving the answer category "always" five grades, the "very often" answer four grades, the answer category "sometimes" three grades, the category "rarely" two grades, and the category "never "one grade. The scores on the instrument sections were calculated at three levels (high, medium, low), according to the average responses of the sample members per item. The three levels are as follows:

- Less than 2.34: low degree of usage.

- 2.34 - less than 3.67: medium degree of usage.

- From 3.67 to 5: high degree of usage.

The previous measure was calculated using the following formula:

Upper Gauge (5) - Lower Gauge (1)

Number of categories required (3) 
The Extent of Using Modern Assessment Strategies and Tools by Teachers of English Language in an EFL Context

$5-1=1.33$

3

Then, the answer (1.33) was added to the end of each category.

\section{Study variables}

This study included two kinds of variables as follows:

A. Independent variables:

-Gender, with two levels: female and male

-Experience, with three levels: (less than 5 years, 5 -10 years, more than 10 years).

-Qualification, with three levels: Bachelor degree, High Diploma and Master's degree.

B. Dependent variables:

Assessment strategies and tools used by teachers of English language.

\section{Statistical Analysis}

To answer the questions of the study, appropriate statistical methods, such as arithmetical means, standard deviations and three-way ANOVA were used.

\section{Results of the Study}

The aim of this study is to identify the level of using modern assessment tools by Teachers of English Language in an EFL context. The results obtained are presented as follows:

Question 1: What is the most common method of assessment used: traditional or modern assessment methods?

To answer this question, means and standard deviations of the assessment strategies used by English teachers were extracted and table (2) below illustrates this.

Table 2: Means and standard deviations of the items of the assessment strategies used by Teachers of English Language arranged in a descending order according to their means

\begin{tabular}{|c|c|c|c|c|c|}
\hline Rank & Number & Item & Mean & $\begin{array}{c}\text { Std. } \\
\text { Deviation }\end{array}$ & Level \\
\hline 1 & 9 & $\begin{array}{l}\text { Teacher depends on pencil and paper: test/ quiz/ } \\
\text { exam, as an assessment strategy }\end{array}$ & 3.88 & 1.068 & High \\
\hline 2 & 10 & $\begin{array}{c}\text { Teacher uses short- term questions: multiple choice } \\
\text { items, match items, true/ false items, as an } \\
\text { assessment strategy }\end{array}$ & 3.86 & 1.052 & High \\
\hline 3 & 11 & $\begin{array}{c}\text { Teacher uses open ended answer items: completion, } \\
\text { short answer, essay and problem solving, as an } \\
\text { assessment strategy }\end{array}$ & 3.80 & 1.026 & High \\
\hline 4 & 12 & Teacher observes students randomly for assessment & 3.79 & 1.026 & High \\
\hline 5 & 8 & $\begin{array}{l}\text { Teacher entirely depends on the curriculum to } \\
\text { provide students with needed information }\end{array}$ & 3.75 & 1.027 & High \\
\hline 6 & 7 & $\begin{array}{l}\text { Teacher encourages students to participate and } \\
\text { discuss during the session. (performance based } \\
\text { assessment) }\end{array}$ & 3.73 & 1.098 & High \\
\hline
\end{tabular}


AlNatour, Hijazi and AlZuraiqih

\begin{tabular}{|c|c|c|c|c|c|}
\hline Rank & Number & Item & Mean & $\begin{array}{c}\text { Std. } \\
\text { Deviation }\end{array}$ & Level \\
\hline 7 & 24 & $\begin{array}{c}\text { Teacher employs communication as an assessment } \\
\text { strategy by using questions and answers } \\
\text { (communication) }\end{array}$ & 3.70 & 1.017 & High \\
\hline 8 & 22 & $\begin{array}{c}\text { Teacher implements self- assessment as a reflection } \\
\text { assessment strategy }\end{array}$ & 3.12 & 1.029 & Medium \\
\hline 9 & 23 & $\begin{array}{c}\text { Teacher implements journal as a reflection } \\
\text { assessment strategy }\end{array}$ & 3.09 & 1.106 & Medium \\
\hline 10 & 1 & $\begin{array}{c}\text { teacher uses presentations as a performance-based } \\
\text { assessment }\end{array}$ & 3.01 & 1.092 & Medium \\
\hline 11 & 2 & $\begin{array}{c}\text { Teacher uses demonstration as a performance- } \\
\text { based assessment }\end{array}$ & 2.98 & 1.45 & Medium \\
\hline 12 & 3 & $\begin{array}{c}\text { Teacher uses speech as a performance-based } \\
\text { assessment }\end{array}$ & 2.96 & .988 & Medium \\
\hline 13 & 5 & $\begin{array}{l}\text { Teacher uses simulation/role playing as a } \\
\text { performance-based assessment }\end{array}$ & 2.89 & 0.978 & Medium \\
\hline 14 & 4 & $\begin{array}{c}\text { Teacher uses debate as a performance-based } \\
\text { assessment }\end{array}$ & 2.33 & 1.203 & Low \\
\hline 15 & 6 & $\begin{array}{c}\text { Teacher uses exhibition as a performance-based } \\
\text { assessment }\end{array}$ & 2.30 & 1.051 & Low \\
\hline 16 & 20 & $\begin{array}{c}\text { Teacher employs communication as an assessment } \\
\text { strategy by using conference }\end{array}$ & 2.29 & 1.112 & Low \\
\hline 17 & 19 & $\begin{array}{c}\text { Teacher employs communication as an assessment } \\
\text { strategy by using interview }\end{array}$ & 2.27 & 1.167 & Low \\
\hline 18 & 18 & $\begin{array}{c}\text { Teacher observes students systematically for } \\
\text { assessment }\end{array}$ & 2.24 & 1.323 & Low \\
\hline 19 & 13 & Teacher uses checklist as an assessment tool & 2.21 & 1.401 & Low \\
\hline 20 & 14 & Teacher uses rating scale as an assessment tool & 2.20 & 0.978 & Low \\
\hline 21 & 15 & Teacher uses rubric as an assessment tool & 2.18 & 1.614 & Low \\
\hline 22 & 21 & $\begin{array}{l}\text { Teacher implements student-portfolio as a } \\
\text { reflection assessment strategy }\end{array}$ & 2.15 & 1.153 & Low \\
\hline 23 & 16 & $\begin{array}{c}\text { Teacher uses anecdotal record as an assessment } \\
\text { tool }\end{array}$ & 2.10 & 1.126 & Low \\
\hline 24 & 17 & $\begin{array}{l}\text { Teacher uses learning log as an assessment tool } \\
\text { Total }\end{array}$ & $\begin{array}{l}2.05 \\
2.94\end{array}$ & $\begin{array}{l}.986 \\
.986\end{array}$ & $\begin{array}{c}\text { Low } \\
\text { Medium }\end{array}$ \\
\hline
\end{tabular}

Table (2) shows that the mean scores ranged between (2.05-3.88), where item (9), which states: "Teacher depends on pencil and paper: test / quiz / exam, as an assessment strategy", ranked first with an arithmetic mean of (3.88), while item (17) "Teacher uses learning log as an assessment tool" ranked last with an average of (2.05). Besides, it is noted that items $(9,10,11,12,8,7,24)$ have means between $(3,70$ 3,88 )which indicates a high degree of usage while items ( 22, 23,1,2,3,5,4,6,20,19,18,13,14,15,21,16,17) have means between $(2,05-3,12)$ which indicates a medium to low degree of usage but mostly low. Items ranked from one to seven represent traditional ways of assessing students' understanding. On the other hand, it can be noticed that items ranked from eight to twenty -four represent the alternative ways of assessment. The final result indicates that teachers tend to use traditional assessment strategies.

Question 2: Are there any statistically significant differences at $(\alpha=0.05)$ in the assessment strategies used by Teachers of English Language due to gender, experience and scientific variables?

To answer this question, the arithmetic means and standard deviations were extracted for the assessment strategies used by English language according to gender, experience and qualification variables. Table (3) below illustrates this: 
The Extent of Using Modern Assessment Strategies and Tools by Teachers of English Language in an EFL Context

Table (3): Means and standard deviations of the assessment strategies used by Teachers of English Language according to gender, experience and qualification variables

\begin{tabular}{lccc}
\hline Variable & Category & Mean & Std. Deviation \\
\hline \multirow{3}{*}{ Gender } & Male & 3.11 & .753 \\
\multirow{3}{*}{ Experience } & Female & 3.19 & .776 \\
& Less than 5 years & 3.14 & .771 \\
Scientific Qualification & 5 years - less than 10 years & 3.18 & .781 \\
& 10 years or more & 3.10 & .733 \\
& B.A. & 3.15 & .772 \\
& Higher Diploma & 3.13 & .788 \\
& M.A. & 3.16 & .713 \\
\hline
\end{tabular}

Table (3) shows a variance in the arithmetical means and standard deviations of the assessment strategies used by Teachers of English Language according to gender, experience and qualification variables. To illustrate the significance of the statistical differences between the arithmetic means, the Three-Way ANOVA test was applied to the instrument as a whole. Table (4) shows the results:

Table (4): Three-Way ANOVA of the arithmetical means and standard deviations of the assessment strategies used by Teachers of English Language according to gender, experience and qualification variables

\begin{tabular}{lccccc}
\hline Source of Contrast & $\begin{array}{c}\text { Sum } \\
\text { Squares }\end{array}$ & $\begin{array}{c}\text { Degrees of } \\
\text { freedom }\end{array}$ & Mean squares & F - Value & $\begin{array}{c}\text { Statistical } \\
\text { significance }\end{array}$ \\
\hline Gender & .189 & 1 & .189 & .093 & .575 \\
Experience & .146 & 2 & .073 & .036 & .885 \\
Qualification & .009 & 2 & .005 & .002 & .992 \\
Error & 74.799 & 37 & 2.02 & & \\
Total & 75.139 & 42 & & & \\
\hline
\end{tabular}

Table (4) shows the following:

- There are no statistically significant differences $(\alpha=0.05)$ due to gender, with a value of.093and a statistical significance of 0.575 .

- There are no statistically significant differences $(\alpha=0.05)$ due to experience, with a value of.036 and a statistical significance of 0.885 .

- There are no statistically significant differences $(\alpha=0.05)$ due to qualifications, with a value of.002and a statistical significance of 0.992 .

\section{Discussion of Findings}

The level of using modern assessment strategies by English teachers to assess students' understanding and enhance their learning ranges between medium and low but it is mostly low, and the previous result may be due to the weakness of English teachers' training on how to use modern strategies. Through personal communication with the teachers (by asking and observing), the researchers noted that the training efforts of the Jordanian Ministry of Education to qualify Teachers of English Language are limited to some aspects of the educational process such as classroom planning and classroom management, or countering students' weakness in English. However, teachers are not sufficiently 
qualified to employ modern assessment strategies within the classroom. On the other hand, the researchers noted that the number of students in the same classroom is high to a level that requires the teacher to use traditional pedagogical methods, both in the process of teaching or evaluation. All the previous factors made English teachers' methods of assessment limited to some modern strategies, although their use is below the required level.

In addition, some teachers have their own concerns about the objectivity of some alternative ways of assessment. Many researchers, such as Law and Eckes (1995), found out that traditional ways of assessment are more valid, reliable and objective since the results of standardized tests and other types of multiple choice tests are totally clear and valid. It is unlike evaluating students by using alternative assessment strategies. The bases on which grades are given to students can vary for different reasons: teachers might be biased to certain students based on their self- reflection and experience; sometimes students themselves do not have the courage to express themselves with the alternative methods teachers use, as they are better at paper-based exams. Some teachers believe, by observing and asking them, that alternative ways of assessment do not help teachers make good educational decisions and that without validity, any assessment is useless. The main reason is that the results of students' achievement are based on an abstract system of grading, and that there are no paper-based marks that both students and parents could see.

One of the reasons that affect the use of modern assessment strategies could be that teachers feel they are going to be evaluated, by both administrative superiors and supervisors or parents, according to students' achievement since the alternative assessment methods are the same in the same group of teachers who teach the same subject; the higher the level of students' achievement is, the more valid the teacher is in the process of teaching. Modern assessment strategies should be collaboratively developed, especially among a group of teachers who teach the same subject. When traditional assessment is used to measure how effective the teaching methods are, or how students' achievement is leveled, teachers are aware of the fact that these methods are also used to measure how effective their methods of teaching are. Another reason to consider is that not all methods of traditional assessment should be categorized or used as a traditional strategy. Students' understanding and achievements vary from one person to another; accordingly, teachers or practitioners should use a variety of techniques and methods to ensure students' understanding and consequently enhance their results.

Sometimes, teachers have some remarks regarding using modern assessment strategies; such strategies sometimes exceed the normal length, fail to be simple in form, and are consequently hard to be analyzed. Teachers need to put extra efforts to plan for assessments that suit all students in order to achieve a more consistent evaluation of students and the way they learn. They find traditional ways of assessing students more suitable for parents to accept because they have paper- based scores that they can deal with. Modern assessment strategies are also, according to some schools, costly. Therefore, some schools try to reduce expenses by using traditional assessments especially when they are restricted by tight budget as some teachers declared when they were asked directly. 
The Extent of Using Modern Assessment Strategies and Tools by Teachers of English Language in an EFL Context

The results of the study have revealed that there are no statistically significant differences in the assessment strategies used by English teachers to evaluate the understanding of the students due to gender, experience and qualification variables. The previous finding seems somewhat logical because English teachers carry out their teaching tasks in a similar and homogeneous environment in which most teachers use the teacher's guide "Teacher's Book" as a key reference in planning for classes. Therefore, teachers' performance in the classroom was almost the same in terms of teaching or evaluation, noting that the performance of females in terms of evaluation was better than that of males, although this was not statistically significant.

\section{Recommendations}

In the light of the results, the researchers recommend the following:

1- The need to plan and prepare mandatory in-service training programs for Teachers of English Language that enable them to implement modern strategies for assessment.

2- The need to provide English teachers with practical models on how to implement appropriate strategies to assess students' understanding;

2- Conducting further studies with different samples in order to form a better integrated picture of the level of using modern assessment strategies in the educational process.

\section{Conclusion}

The results of the current study indicate, through using arithmetical means, standard deviations and Three-way ANOVA, that teachers have a tendency to use the traditional assessment strategies rather than alternative modern ones. The results have shown that teachers are more satisfied with the traditional ways of assessment, such as paper-based test/ quiz/ exam, short-term questions as well as open-ended answer, as valid measures of student competence. Furthermore, most teachers still use random observation for measuring students' ability. However, teachers should implement the new assessment strategies in order to enhance students' achievement. In addition, they should implement a variety of assessing methods to ensure that students' understanding improves when using different strategies, and this will result in higher student achievement. 
AlNatour, Hijazi and AlZuraiqih

$$
\begin{aligned}
& \text { مدى استخدام معلمي اللفة الإنجليزية لاستراتيجيات التقييم الحديثة } \\
& \text { وأدواته في بيئة تدريس اللفة الإنجليزية كلفة أجنبية } \\
& \text { أمل الناطور، ديما حجازي }
\end{aligned}
$$

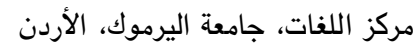

$$
\begin{aligned}
& \text { هبة الزريق } \\
& \text { القلقشندي للكتابة والبحوث، الأردن الزريف }
\end{aligned}
$$

\section{الملخص}

تهدف هذه الدراسة إلى الكثف عن مستوى استخدام استراتجيات التقييم الحديثة وأدواته من قبل معلمي اللفة الإنجليزية كلفة أجنية في البيئة الأردنية لكونه مكوناً أساسياً وضرورياً في عمليتي التعلم والتعليم. اشتملت هذه الدراسة على ثلاثة متفيرات وهي: الجنس والخبرة والمؤهلات العلمية.كما اقتصرت الدراسة على معلمي اللفة الإنجليزية كلفة أجنبية لسنة 2020/2019. ولتحقيق أهداف الدراسة، فقد اختيرت عينة عشوائية مكونة من 43 معلماً من محافظة إربد.وقد استخدمت الدراسة المنهج التحليلي الوصفي باستخدام مقياس ليكرت الخماسي الأبعاد أداة للدراسة. وأظهرت نتائج هذه الدراسة أن مستوى استخدام وسائل التقييم الحديثة من معلمي اللفة الإنجليزية في تقييم مدى فهم الطلبة وتعزيز العملية التعليمية تتراوح ما بين المتوسط والمنخفض وعلى الأغلب منخفض. ولوحظ أيضًا أن تطبيق بعض الفقرات التي تمثًّ وسائل التقييمم التقليدية الثـائعة كان بمستوى أعلى من تطبيق بقية الفقرات الأخرى التي تمثل وسائل التقييمم الحديثة. وأظهرت النتائج النهائية أيضًا أن المعلمين يستخدمون وسائل التقييمم التقليدية بثكل أعلى لأسباب مختلفة تم عرضها في قسم مناقشة النتائج. علاوة على ذلك، فقد أظهرت النتائج أيضاً بأنه لا يوجد هنالك فروق ذات دلالة إحصائية تعود إلى الجنس أو الخبرة أو المؤهل العلمي. الكلمات المفتاحية: استراتجيات التقييم، بيئة تدريس اللفة الإنجليزية كلفة أجنبية، استراتيجيات التقييم التقليدية، استراتيجيات التقييم الحديثة. 
The Extent of Using Modern Assessment Strategies and Tools by Teachers of English Language in an EFL Context

\section{References}

Aitken, Nola, and Lydia Pungur. 2005. Authentic assessment: http://www.ntu.edu.vn/Portals/96 /.../authentic\%20assessment\%202.pdf (Accessed June 21 2010)

Allen, Mary. J. 2004. Assessing academic programs in higher education. Bolton, Mass: Anker Pub. Co.

Angelo, Thomas. A. 1995. Reassessing (and redefining) assessment. AAHE Bulletin, 48 (2): 7-9.

Black, Paul, and Dylan Wiliam. 1998. Assessment and classroom learning. Assessment in education: Principles, policy \& practice, 5 (1): 7-74. DOI: 10.1080/0969595980050102

Birenbaum, Menucha, and Filip J.R.C. Dochy. 1996. Alternatives in assessment of achievements, learning processes and prior knowledge. Boston, MA: Kluwer/Springer.

Buhagiar, Michael. 2007. Classroom assessment within the alternative assessment paradigm: Revisiting the territory. Curriculum Journal, 18 (1): 39-56.Doi.org/10.1080/09585170701292174. https://onlinelibrary.wiley.com/doi/abs/10.1080/09585170701292174

Chappuis, Stephen, and Jan Chappuis. 2008. The best value in formative assessment. Educational Leadership, 65: 14-19. Google Scholar

Dandis, Maha.A. 2013. The assessment methods that are used in a secondary school mathematics classes. Journal of Educators, Teachers and Trainers, 4(2): 133-143.

Dhindsa, Harkirat, Khalid Omar, and Bruce Waldrip. 2007. Upper Secondary Bruneian Science Students' perceptions of assessment. International Journal of Science Education, 29(10): 1261-1280.

Dikli, Semire. 2003. Assessment at a distance: Traditional vs. alternative assessments. The Turkish Online Journal of Educational Technology-TOJET2 (3):13-19.

Dumit, Nuhad.Y. 2012. Diagnostic/Formative/Summative assessment. aub.edu.lb/.../Documents/ CLO\%20summer\%202012/Diagnostic\%20formative\%20su. (Accessed July 6, 2020)

Dochy, Filip J.R.C, and Liz McDowell. 1997. Introduction: Assessment as a tool for learning. Studies in Educational Evaluation, 23(4): 279-298. DOI 10.1016/S0191-491X (97)86211-6.

Dunn, lee, Chris Morgan, and Meg O'Reilly. 2003. The Student assessment handbook: New directions in traditional and online assessment. Routledge Falmer. New York.

Forutan, Ali. 2014. Traditional versus alternative writing assessment. International Journal of Foreign Language Teaching \& Research, 2(7): 10-22.

Gahagan, Jimmie, John Dingfelder, and Katherine Pei. 2010. A faculty and staff guide to creating learning outcomes. Columbia, SC: University of South Carolina.

Gardiner, Lion. F. 1994. Redesigning higher education: Producing dramatic gains in student. ASHE-ERIC Higher Education Report, 23(7). ERIC

Goodrum, Denis, Mark Hackling, and Leonie Rennie. 2001. The status and quality of teaching and learning of science in Australian schools: A research report. Department of Education, Training and Youth Affairs, Canberra: Commonwealth of Australia. 
AlNatour, Hijazi and AlZuraiqih

Grant, Janet. 2002. Learning needs assessment: Assessing the need. British Medical Journal, 324, (7330): 156-159. http://www.bmj.com (Accessed May 25, 2020)

Heritage, Margaret. 2008. Learning progressions: Supporting instruction and formative assessment. Paper prepared for the Formative Assessment for Teachers and Students (FAST) State Collaborative on Assessment and Student Standards (SCASS) of the Council of Chief State School Officers (CCSSO).University of California, Los Angeles.

Huba, Mary. E, and Jann Freed. E. 2000. Learner-centered assessment on college campuses: Shifting the focus from teaching to learning. London: Pearson.

Jacobs, George, and Thomas Farrell. 2003. Understanding and implementing the CLT Paradigm. RELC Journal, 41(1):5-30.

Janish, Carole, Xiaoming Liu, and Amma Akrofi. 2007. Implementing alternative assessment: Opportunities and obstacles. The Educational Forum, 71: 221-229.

Kanjee, Anil, and Jane Mthembu. 2015. Assessment literacy of foundation phase teachers: An exploratory study. South African Journal of Childhood Education, 5(1): 142-168.

Law, Barbara , and Mary Eckes. 1995. Assessment and ESL. Manitoba, Canada: Peguis publishers.

Looney, Janet. W. 2011. Integrating formative and summative assessment: Progress toward a seamless system? OECD Education Working Papers, 58, Paris: OECD.

Mussawy Sayed. 2009. Assessment practices: Students' and teachers' perceptions of classroom assessment. PhD diss., Center for International Education: University of Massachusetts - Amherst.

National Research Council. 2000. Educating teachers of science, mathematics, and technology: New practices for the new millennium. Washington, DC: The National Academies Press. https://doi.org/10.17226/9832.

Nitko, Anthony. 1989. Educational measurement: Issues and practice. NCME, 8 (1): 4-41. Wiley Online Library. https://doi.org/10.1111/j.1745-3992.1989.tb00302.x

Pellegrino, James. W., Naomi Chomsky, and Robert Glaser. eds. 2001. Knowing what students know: The science of design and educational assessment. Washington, DC: National Academies Press.

Quansah, Frank. 2018. Traditional or performance assessment: What is the right way in assessing learners? Research on Humanities and Social Sciences, 8(1): 21-24.

Fazlur Rahman, Md, Rasel Babu, and Md Ashrafuzzaman. 2011. Assessment and feedback practices in the English Language classroom. Nepal English Language Teachers' Association, 16 (1-2): 97-106.

Shepherd, Eric, and Janet Godwin. 2004. Assessments through the learning process. White paper published at http://www.questionmark.com.

Shohamy, Elana, Ofra Inbar-Lourie, and Matthew E. Poehner. 2008. Investigating assessment perceptions and practices in the advanced Foreign Language classroom. University Park, PA: Center for Advanced Language Proficiency Education and Research. 
The Extent of Using Modern Assessment Strategies and Tools by Teachers of English Language in an EFL Context

Simonson Michael, Sharon Smaldino, Michael Albright, andSusan Zvacek. 2000. Assessment for distance education. In Teaching and learning at a distance: Foundations of distance education. Upper Saddle River, NJ: Prentice-Hall, ch. 11.

The Glossary of Education Reform. 2014. http://edglossary.org/assessment/.

The office of assessment University of Connecticut. (n.d). Why assessment? http:// assessment. education. uconn.edu (Accessed May 30, 2010)

Wiliam, Dylan. 2013. Assessment: The bridge between teaching and learning. Voices from the Middle, 21(2): 15-20.

Wiliam, Dylan, and Marnie Thompson. 2008. Integrating assessment with instruction: What will it take to make it work? NJ: Lawrence Erlbaum Associates. .53-82.

Yamtim, Varaporn, and Suwimon Wongwanich. 2014. A study of classroom assessment literacy of primary school teachers. Procedia-Social and Behavioral Sciences, 116: 2998-3004.

\section{Appendix A}

Questionnaire

This questionnaire is oriented to investigate the types of assessment Jordanian teachers at the public and private sectors use to measure students' understanding, and subsequently their achievement.

a. Teaching experience

b. Gender

c. Qualifications

\section{Table1:}

\begin{tabular}{|c|c|c|c|c|}
\hline No. & Item & Yes & No & Sometimes \\
\hline 1. & $\begin{array}{l}\text { Teacher uses presentations as a performance-based } \\
\text { assessment }\end{array}$ & & & \\
\hline 2. & $\begin{array}{l}\text { Teacher uses demonstration as a performance-based } \\
\text { assessment }\end{array}$ & & & \\
\hline 3. & $\begin{array}{l}\text { Teacher uses speech as a performance-based } \\
\text { assessment }\end{array}$ & & & \\
\hline 4. & $\begin{array}{l}\text { Teacher uses debate as a performance-based } \\
\text { assessment }\end{array}$ & & & \\
\hline 5. & Teacher uses simulation/role playing as a & & & \\
\hline
\end{tabular}


AlNatour, Hijazi and AlZuraiqih

\begin{tabular}{|c|c|c|c|c|}
\hline No. & Item & Yes & No & Sometimes \\
\hline & performance-based assessment & & & \\
\hline 6. & $\begin{array}{l}\text { Teacher uses exhibition as a performance-based } \\
\text { assessment }\end{array}$ & & & \\
\hline 7. & $\begin{array}{l}\text { Teacher encourages students to participate and } \\
\text { discuss during the session. }\end{array}$ & & & \\
\hline 8. & $\begin{array}{l}\text { Teachers entirely depends on the curriculum to } \\
\text { provide students with information needed }\end{array}$ & & & \\
\hline 9. & $\begin{array}{l}\text { Teacher depends on pencil and paper: test/ quiz/ } \\
\text { exam, as an assessment strategy }\end{array}$ & & & \\
\hline 10. & $\begin{array}{l}\text { Teacher uses short- term questions: multiple choice } \\
\text { items, match items, true/ false items, as an } \\
\text { assessment strategy }\end{array}$ & & & \\
\hline 11. & $\begin{array}{l}\text { Teacher uses open ended answer items: completion, } \\
\text { short answer, essay and problem solving, as an } \\
\text { assessment strategy }\end{array}$ & & & \\
\hline 12. & teacher observes students randomly for assessment & & & \\
\hline 13. & Teacher uses check list as an assessment tool & & & \\
\hline 14. & Teacher uses rating scale as an assessment tool & & & \\
\hline 15. & Teacher uses rubric as an assessment tool & & & \\
\hline 16. & Teacher uses anecdotal record as an assessment tool & & & \\
\hline 17. & Teacher uses learning log as an assessment tool & & & \\
\hline 18. & $\begin{array}{l}\text { teacher observes students systematically for } \\
\text { assessment }\end{array}$ & & & \\
\hline 19. & $\begin{array}{l}\text { Teacher deploys communication as an assessment } \\
\text { strategy by using conference and interview }\end{array}$ & & & \\
\hline 20. & $\begin{array}{l}\text { Teacher implements student-portfolio as a reflection } \\
\text { assessment strategy }\end{array}$ & & & \\
\hline 21. & $\begin{array}{l}\text { Teacher implements self- assessment as a reflection } \\
\text { assessment strategy }\end{array}$ & & & \\
\hline 22. & $\begin{array}{l}\text { Teacher implements journal as a reflection } \\
\text { assessment strategy }\end{array}$ & & & \\
\hline 23. & $\begin{array}{l}\text { Teacher deploys communication as an assessment } \\
\text { strategy by using questions and answers }\end{array}$ & & & \\
\hline 24. & Teacher prefers using traditional ways of assessment & & & \\
\hline 25. & Teacher prefers using alternative ways of assessment & & & \\
\hline
\end{tabular}


The Extent of Using Modern Assessment Strategies and Tools

by Teachers of English Language in an EFL Context

\section{Appendix B}

Table 2: Correlation coefficients between the items and the questionnaire as a whole

\begin{tabular}{|c|c|c|c|}
\hline Item No. & $\begin{array}{c}\text { Correlation coefficients } \\
\text { with the questionnaire }\end{array}$ & Item no. & $\begin{array}{c}\text { Correlation coefficients } \\
\text { with the questionnaire }\end{array}$ \\
\hline 1 & $.72^{* *}$ & 11 & $.92^{* *}$ \\
\hline 2 & $.76^{* *}$ & 12 & $.82^{* *}$ \\
\hline 3 & $.81^{* *}$ & 13 & $.70^{* *}$ \\
\hline 4 & $.80^{* *}$ & 14 & $.89^{* *}$ \\
\hline 5 & $.71^{* *}$ & 15 & $.91^{* *}$ \\
\hline 6 & $.72^{* *}$ & 16 & $.77^{* *}$ \\
\hline 7 & $.88^{* *}$ & 17 & $.76^{* *}$ \\
\hline 8 & $.69^{* *}$ & 18 & $.84^{* *}$ \\
\hline 9 & $.74^{* *}$ & 19 & $.90^{* *}$ \\
\hline 10 & $.90^{* *}$ & 20 & $.88^{* *}$ \\
\hline 21 & $.79^{* *}$ & 22 & $.64^{* *}$ \\
\hline 23 & $.80^{* *}$ & 24 & $.88^{* *}$ \\
\hline
\end{tabular}

** Statistically significant at level (0.01).

It should be noted that all correlation coefficients were acceptable and statistically significant, therefore, none of these items was deleted. 